\title{
PRESTASI BELAJAR \\ Pada MATA PELAJARAN PENDIDIKAN AGAMA ISLAM (PAI) \\ SISWA SEKOLAH MENENGAH PERTAMA (SMP) NEGERI 7 KOTA CIREBON (KOMPARASI SISWA KELUARGA PEGAWAI NEGERI SIPIL Dan SISWA KELUARGA BURUH)
}

\author{
Muhamad Yusuf, Nurlela \\ Fakultas Ilmu Tarbiyah dan Keguruan \\ Institut Agama Islam Negeri Syekh Nurjati Cirebon \\ Email : iyusmuhamad989@gmail.com
}

\begin{abstract}
ABSTRAK
Penelitian dalam skripsi ini tentang prestasi pada mata pelajaran Pendidikan Agama Islam (PAI). Selama ini asumsi yang muncul bahwa, orang tua yang pekerjaaya buruh maka prestasi belajar anak rendah, sedangkan orang tua yang pekerjaannya Pegawai Negeri Sipil (PNS) prestasi anaknya tinggi. Namun berdasarkan studi kasus di sini tidak mutlak terjadi karena adanya prestasi belajar Pendidikan Agama Islam (PAI) yang sangat baik untuk siswa keluarga ekonomi rendah (Buruh) dengan rata-rata nilai > 80. Oleh karena itu penelitian ini ingin mengetahui perbedaan prestasi belajar siswa keluarga Pegawai Negeri Sipil dengan siswa keluarga Buruh Pada Mata Pelajaran Pendidikan Agama Islam (PAI) di Sekolah Menengah Pertama (SMP) Negeri 7 Kota Cirebon.

Tujuan penelitian ini adalah Untuk mengetahui prestasi belajar siswa Pegawai Negeri Sipil dan siswa keluarga Buruh. Selain itu untuk mengetahui perbedaan prestasi belajar antara siswa keluarga Pegawai Negeri Sipil dengan siswa keluarga Buruh.

Penelitian ini memiliki kerangka pemikiran bahwa prestasi belajar pada dasarnya adalah tingkat keberhasilan yang dicapai dari suatu kegiatan atau usaha yang dapat diukur dengan alat atau tes tertentu setelah seseorang belajar. pekerjaan buruh diartikan sebagai orang yang bekerja dibawah perintah orang lain, dengan menerima upah karena telah melakukan pekerjaan diperusahaan. Sedangkan pegawai umumnya adalah mereka yang bekerja diinstansi pemerintahan yang disebut Pegawai Negeri Sipil.
\end{abstract}


Jenis data yang digunakan peneliti ialah menggunakan data kuantitatif. Teknik pengumpulan data yang digunakan adalah: observasi, wawancara, dokumentasi, dan studi pustaka. Sedangkan untuk analisis yaitu menggunakan Uji t.

Kesimpulan dari hasil analisis peneliti yaitu Prestasi belajar pada mata pelajaran Pendidikan Agama Islam (PAI) siswa kelurga PNS SMP Negeri 7 kota Cirebon diketahui bahwa dalam katagori Cukup. Dilihat dari nilai menunjukan perolehan perhitungan ratarata (Mean) 71,42. Prestasi belajar pada mata pelajaran Pendidikan Agama Islam (PAI) siswa kelurga Buruh SMP Negeri 7 kota Cirebon diketahui dalam katagori Baik. Dilihat dari nilai menunjukan perolehan perhitungan rata-rata (Mean) 80,64. Hasil Uji- T menunjukan Sig. (2- tailed) 0,000< $<(0,05)$ sehingga $H_{0}$ ditolak dan $H_{a}$ diterima yang berarti terdapat Perbedaan yang Signifikan antara prestasi belajar keluarga PNS dengan siswa keluarga Buruh

\section{Kata kunci: Prestasi Belajar, Pekerjaan Orang Tua}




\section{A. PENDAHULUAN}

Pendidikan merupakan pilar utama dalam membangun bangsa. Tinggi rendahnya derajat suatu bangsa ditentukan kualitas pendidikan masyarakatnya. Karenanya dengan pendidikan yang tepat akan melahirkan anak-anak bangsa yang bermoral, cerdas, memiliki etos kerja dan inovasi yang tinggi. Oleh sebab itu penting dalam sebuah tujuan pendidikan adalah menumbuhkan dan mengembangkan seluruh potensi yang dimiliki manusia sehingga berakhlak mulia, berfikir cerdas, kuat dan kreatif, inisiatif dan responsif. Anak yang dilahirkan dengan "kemurnian" sangat dipengaruhi oleh apa yang akan ditorehkan dalam lingkungan pendidikannya. ${ }^{1}$

Sebagai akibat dari perkembangan dan teknologi di negara kita, maka fungsi dan tujuan pendidikan nasional dirumuskan kembali dalam UU RI Nomor 20 tahun 2003 tentang Sistem Pendidikan Nasional yang berbunyi sebagai berikut:

"Pendidikan nasional berfungsi mengembangkan kemampuan dan membentuk watak serta peradaban bangsa yaang bermartabat dalam rangka mencerdaskan kehidupn bangsa dan bertujuan untuk berkembangnya potensi peserta didik agar menjadi manusia yang beriman dan bertaqwa pada Tuhan Yang Maha Esa, berakhlak mulia, sehat, berilmu, cakap, kreatif, mandiri, dan menjadi warga negaraa yaang demokratis serta bertaanggung jawab." (UU Sisdiknas 2003).

Tentang hak dan kewajiban orang tua Undang Undang Sistem Pendidikan Nasional (Sisdiknas) Pasal 7 ayat 1 bahwa orang tua berhak berperan serta dalam memilih satuan pendidikan dan memperoleh informasi tentang perkembangan pendidikan anaknya. ${ }^{2}$

Dalam proses pembelajaran di sekolah perlu diadakannya tes prestasi belajar untuk mengukur hasil pembelajaran yang diperoleh siswa dalam mempelajari materi pelajaran yang telah diberikan guru kepada siswanya. Prestasi belajar pada dasarnya adalah hasil akhir yang diharapkan dapat dicapai setelah seseorang belajar. Menurut Ahmad Tafsir hasil belajar atau bentuk perubahan tingkah laku yang diharapkan itu merupakan suatu target atau tujuan pembelajaran yang meliputi tiga aspek, yaitu; 1) tahu, mengetahui (Knowing); 2) terampil melaksanakan atau mengerjakan yang ia ketahui itu (doing); dan

${ }^{1}$ Amirah,"Mendidikan Anak di Era Digital" (Surabaya: LaksBang Pressindo, 2010), 3.

2 UU RI No. 20. 2003, "Sistem Pendidikan Nasional" (Jakarta.Sinar Grafika, 2003), 9. 
3) melaksanakan yang ia ketahui itu secara rutin dan konsekuen (being). ${ }^{3}$ Adapun menurut Benjamin S. Bloon, sebagaimana yang dikutip oleh Abu Muhammad Ibnu Abdullah bahwa hasil belajar diklasifikasikan ke dalam tiga ranah yaitu: 1). Ranah kognitif (cognitive domain); ranah afektif (affektive domain); dan 3) ranah psikomotor (psychomotor domain).

Faktor-faktor yang dapat memengaruhi prestasi belajar dan mengklasifikasikannya menjadi dua bagian, yaitu: 1) faktor-faktor intern; dan 2) faktor-faktor ekstern. ${ }^{4}$ Faktorfaktor intern, yakn faktor-faktor yang berasal dari dalam diri seseorang yang dapat memengaruhi prestasi belajarnya. Di antara faktor-faktor intern yang dapat memengaruhi prestasi belajar seseorang adalah antara lain: a. kecerdasan, b. bakat, c. Minat, d. Motivasi. Adapun faktor-faktor ekstern, yaitu faktor-faktor yang dapat memengaruhi prestasi belajar seseorang yang sifatnya berasal dari luar diri seseorang tersebut. Yang termasuk faktorfaktor ini adalah antara lain: 1) Keadaan lingkungan keluarga, 2). Keadaan lingkungan sekolah, dan 3) keadaan lingkungan masyarakat.

Salah satu faktor yang memengaruhi prestasi belajar siswa yang berasal dari luar siswa di atas yaitu lingkungan keluarga. Dalam lingkungan keluarga yang terdiri dari orang tua dan anak, ayah dan ibu memiliki kedudukan sama yaitu sebagai orang tua.

Allah SWT berfirman dalam Q.S. An- Nisa (4) ayat 9, berikut:

"Dan hendaklah takut kepada Allah orang-orang yang seandainya meninggalkan dibelakang mereka anak-anak yang lemah, yang mereka khawatir terhadap (kesejahteraan) mereka. Oleh sebab itu hendaklah mereka bertakwa kepada Allah dan hendaklah mereka mengucapkan perkataan yang benar".

Hal tersebut sejalan dengan sabda Rasulullah SAW., dalam hadits Bukhari, ${ }^{5}$ berikut: 2004), 208.

${ }^{3}$ Ahmad Tafsir, dkk. "Cakrawala Pemikiran Pendidikan Islam". Bandung: Mimbar Pustaka,

${ }^{4}$ Rohmalina Wahab, "Psikologi Belajar" (Depok: PT. Rajagrafindo Persada, 2016), 244-248.

${ }^{5}$ Al-Imam Al-Bukhari, Shahih Bukhari. (Bairut: Dar Al-Kutub Al-Ilmiyah, 2009), 182. 


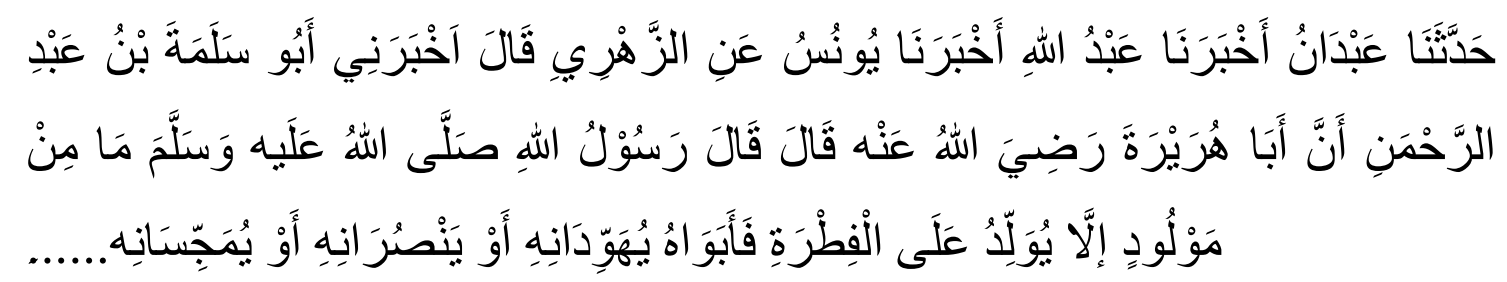

“Telah menceritakan kepada Adam telah menceritakan kepada kami Ibnu Abu Dza'bin dari Az-Zuhriyyi dari Abu Salamah bin Abdur Rahman dari Abu Hurairah berkata: Nabi SAW bersabda: Setiap anak dilahirkan dalam keadaan fitrah. Kemudian kedua orang tuanyalah yang menjadikan anak itu menjadi Yahudi, Nashrani atau Majusi... (H.R. Bukhari).”

Dengan memahami ayat dan hadist tersebut di atas tentulah kita sepakat bahwa orang tua memiliki peranan dan tanggung jawab yang sangat besar dalam menciptakan sebuah lingkungan dan tatanan pendidikan yang baik bagi setiap anak di negeri ini. Kualitas pendidikan yang tentunya akan membawa kepada terbentuknya anak yang berkualitas. Begitupun sebaliknya, dengan pendidikan yang sangat terbatas akan terbentuk kualitas anak yang terbatas pula.

Menurut Ahmad Tafsir, $\mathrm{dkk}^{6}$, menyatakan bahwa dalam Islam telah digariskan lima kewajiban orang tua, yakni tanggung jawab pendidikan dan pembinaan aqidah, tanggung jawab pendidikan dan pembinaan akhlak, tanggung jawab pemeliharaan kesehatan, tanggung jawab pendidikan dan intelektual, serta tanggung jawab kepribadian dan sosial remaja.

Tanpa banyak disadari ternyata banyak gangguan belajar pada anak justru datang dari kita sebagai orang tua. Apabila itu berupa harapan-harapan yang tidak realitas, targettarget yang tidak memenuhi potensi dan kemampuan anak. Perilaku orang tua yang tidak mau tahu tentang kesulitan anak. Menjadi lebih bijak bila ada keinginan dalam diri untuk melakukan introspeksi, sekaligus berupaya untuk senantiasa melakukan perbaikan atas peran dan fungsi sebagai orang tua. ${ }^{7}$

Salah satu permasalahan yang sering dihadapi setiap keluarga adalah tidak adanya keharmonisan dalam hubungan antara orangtua dan anak. Banyak para orang tua yang sudah berbuat banyak untuk sang buah hati, namun tidak mendapatkan hal yang berarti.

${ }^{6}$ Ahmad Tafsir, "Cakrawala Pemikiran Pendidikan Islam", 114.

${ }^{7}$ Amirah, "Mendidikan Anak di Era Digital", 4-5. 
Tidak sedikit anak di dunia yang terjebak pada pola didik orang tua yang tidak sesuai dengan keinginan mereka, sehingga anak menjadi korban. Sampai akhirnya banyak anakanak yang ketika tumbuh besar malah mencari perhatian orangtua dalam bentuk kenakalan yang tidak wajar di luar rumah. Bahkan tidak sedikit, anak-anak yang terlena dengan obatobatan psikotropika, seks bebas dan genk motor yang banyak bersifat anarkis. Sangat disayangkan apabila calon-calon penerus bangsa harus terkikis moral dan akhlaknya hanya karena kesalahan sebagai orang tua yang kurang sensitif dalam memahami prilaku perkembangan anak.

Ada keluarga yang miskin, ada pula yang kaya. Ada kelaurga yang diliputi oleh suasana tenteram dan damai, tetapi ada pula yang sebaliknya, ada keluarga yang terdiri dari ayah-ibu yang terpelajar dan ada pula yang kurang pengetahuan. Ada keluarga yang mempunyai cita-cita bagi anak-anaknya, ada pula yang biasa saja. Suasana dan keadaan keluarga yang bermacam-macamm itu mau tidak mau turut menentukan bagaiman dan samapai dimana belajar dialami dan dicapai oleh anak-anak. ${ }^{8}$

Hidup tentunya tidak sempurna bagi para siswa dari keluraga Status Sosial Ekonomi (SES) tinggi. Sebagai contoh, para orang tua keluarga berpenghasilan tinggi dapat memberikan begitu banyak tekanan pada anak-anak mereka untuk berprestasi tinggi sehingga anak-anak mereka mengalami kecemasan besar dan depresi. Selain itu, para orang tua tersebut mungkin memiliki pekerjaan yang penuh tuntutan dan membuat mereka jauh secara fisik dan emosional dari anak-anak mereka yang pada gilirannya membatasi bimbingan dan dukungan yang bisa mereka berikan kepada anak-anak mereka. ${ }^{9}$

Sedangkan mayoritas orang tua dalam keluarga berpenghasilan rendah menginginkan anak-anak mereka memperoleh pendidikan yang baik Sebagian orang tua dalam rumah tangga Sosial Ekonomi (SES) rendah aktif berinvestasi dalam pendidikan anak-anak mereka, dan hasilnya adalah tingginya prestasi anak-anak tersebut. ${ }^{10}$ Demikianlah seorang penyelidik Jerman, Prestel (21), telah membandingkan prestasi anakanak sekolah kelas pertama dari beberapa sekolah dasar di sebuah kota Jerman Barat. Ia menghitung angka rata-rata rapor kelas pertama dari anak-anak yang berasal dari rumah

\footnotetext{
${ }^{8}$ M. Ngalim Purwanto, Psikologi Pendidikan (Bandung: PT. Remaja Rosdakarya, 2013), 104.

9 Jeanne Ellis Ormroad, "Psikologi Pendidikan" (Jakarta: Penerbit Erlangga, 2008), 187.

${ }^{10}$ (Gutman \& McLoyd, 2000; Jimerson dkk., 1999). (Jeanne Ellis Ormrod, 2008: 189)
} 
tangga yang status sosial-ekonominya rendah, dibandingkannya dengan angka rata-rata ropor kelas pertama anak-anak yang berasal dari keluarga yang statusnya tinggi. Sebagai hasil percobaan ini ditemukannya bahwa prestasi anak-anak dari keluarga yang rendah status sosial-ekonominya pada akhir kelas pertama lebih tinggi dari pada prestasi anakanak dari keluarga yang status sosial-ekonominya tinggi. ${ }^{11}$

Banyak orang tua bahwa kesibukan telah merampas waktunya untuk mendidik anakanaknya. ${ }^{12}$ Pada kenyataannya sesuai pendapat di atas orang tua yang pekerjaan (Pegawai Negeri sipil) terlalu disibukkan dengan aktifitasnya, diantaranya adalah aktifitas mencari nafkah dengan bekal ilmu yang diperoleh orang tua melalui pendidikan. Sehingga kurang mampu menjalani peran utamanya sebagai orang tua dalam keluarga dengan maksimal. Selain itu orang tua yang memiliki penghasilan tinggi akan cenderung menganggap ilmu yang diperoleh dibidang pendidikannya sia-sia, sehingga tidak menyadari pentingnya pekerjaan dan mengabaikan pendidikan anaknya. Sehingga orang tua tersebut gagal menciptakan anak yang berpestasi.

Sedangkan orang tua pekerjaan (Buruh) dan merasa kurang sukses dengan yang di perolehnya saat ini terkadang justru mampu menciptakan anak yang lebih berkualitas darinya. Karena dengan belajar pada pengalamannya yang kurang berhasil dalam kehidupannya dikarenakan dia kurang memiliki pendidikan yang tinggi maka dia akan memperhatikan pendidikan anaknya dengan baik sehingga mampu menciptakan seorang anak yang memiliki prestasi belajar yang baik.

Dari asumsi yang muncul, masyarakat berpandangan dalam dunia pendidikan bahwa orang tua pekerjaan (Buruh) maka prestasi belajar anak rendah. Dan orang tua pekerjaan (Pegawai Negeri Sipil) maka prestasi anak tinggi.

Namun berdasarkan hasil dari studi kasus oleh penulis hal tersebut tidak mutlak terjadi karena di Sekolah Menengah Pertama (SMP) Negeri 7 Kota Cirebon. Menurut penulis layak untuk diteliti yaitu adanya prestasi belajar Pendidikan Agama Islam (PAI) yang sangat baik untuk siswa keluarga ekonomi rendah (Buruh) dengan rata-rata nilai >80 yang kemungkinan siswa ini dipengaruhi oleh faktor luar dalam belajarnya. Siswa dari keluarga buruh memiliki kecerdesan kognitif baik itu cerdas dalam ilmu agama maupun

${ }^{11}$ WA Gerungan, "Psikologi Sosial" (Jakarta: PT Rineka Cipta, 1988), 183.

12 Amirah, "Mendidikan Anak di Era Digital", 5. 
ilmu umum yang tidak disadari oleh orang tua mereka sehingga siswa tersebut prestasinya bagus. Padahal seharusnya prestasi siswa keluarga pekerjaan (PNS) prestasinya lebih baik. Hal ini disebabkan siswa keluarga PNS memiliki sarana prasarana belajar yang relatif mencukupi dan motivasi belajar yang lebih tinggi. Sementara itu keluarga buruh lebih banyak memperhatikan kebutuhan primer sehari-hari dari pada kebutuhan prasarana untuk belajar.

Berdasarkan latar belakang di atas, maka penulis tertarik untuk mengadakan penelitian dengan judul "Perbedaan Prestasi Belajar siswa keluarga Pegawai Negeri Sipil (PNS) dengan siswa keluarga Buruh Pada Mata Pelajaran Pendidikan Agama Islam (PAI) Siswa Sekolah Menengah Pertama (SMP) Negeri 7 Kota Cirebon”, yaitu dengan perumusan masalah, apakah ada perbedaan prestasi belajar siswa keluarga PNS dengan keluarga buruh pada mata pelajaran PAI?

\section{B. PEMBAHASAN}

\section{Pengertian Prestasi Belajar}

Istilah prestasi belajar terdiri dari dua suku kata, yaitu prestasi dan belajar. Istilah prestasi di dalam Kamus Ilmiah Populer didefinisikan sebagai hasil yang telah dicapai. ${ }^{13}$

Menurut Syaiful Bahri Djamarah prestasi adalah hasil dari suatu kegiatan yang telah dikerjakan, diciptakan, yang menyenangkan hati yang diperoleh dengan keuletan kerja, baik secara individual maupun kelompok dalam bidang kegiatan tertentu.

Adapun belajar menurut pengertian secara psikologis, adalah merupakan suatu proses perubahan yaitu perubahan tingkah laku sebagai hasil dari interaksi dengan lingkungannya dalam memenuhi kebutuhan hidupnya. ${ }^{14}$

Menurut pendapat Muhibbin Syah belajar adalah kegiatan yang berproses dan merupakan unsur yang sangat fundamental dalam penyelenggaraan setiap jenis dan jenjang pendidikan. Ini berarti bahwa berhasil atau gagalnya pencapaian tujuan pendidikan

\footnotetext{
${ }^{13}$ Rohmalina wahab, "Psikologi Belajar", 242.

${ }^{14}$ Mulyono, "Buku Ajar Pendidikan Islam" (Jakarta: Rineka Cipta, 2009), 57.
} 
itu amat bergantung pada proses belajar yang dialami siswa, baik ketika ia berada di sekolah maupun dilingkungan rumah atau keluarganya sendiri. ${ }^{15}$

Nana Sudjana mengatakan bahwa belajar adalah suatu proses yang di tandai dengan perubahan pada diri seseorang. Dengan kata lain dengan adanya suatu proses yang dilakukan seseorang akan tercipta perubahan berupa pengetahuan, pemahaman, sikap, tingkah laku, keterampilan, kecakapan dan kemampuannya. ${ }^{16}$

Sedangkan pendapat Slameto belajar ialah suatu proses usaha yang dilakukan seseorang untuk memperoleh suatu perubahan tingkah laku yang baru secara keseluruhan, sebagai hasil pengalamannya sendiri dalam interaksi dengan lingkungannya.

Dari berbagai pengertian belajar yang dikemukakan di atas, secara umum penulis dapat disimpulkan bahwa belajar merupakan suatu proses pengalaman dan latihan melalui interaksi dengan lingkungannya sehingga menghasilkan suatu perubahan pada diri seseorang yang berupa sikap, tingkah laku, pengetahuan, pemahaman, keterampilan serta kemampuannya dibidang tertentu. ${ }^{17}$

Karena belajar adalah suatu proses, maka dari proses tersebut pastilah akan menghasilkan suatu hasil. Hasil dari suatu proses itulah yang merupakan prestasi. Prestasi merupakan hasil yang dicapai seseorang setelah mengerjakan sesuatu. Jadi, hasil dari suatu proses belajar itu merupakan prsetasi belajar. Hal ini sesuai dengan yang dikatakan Muhibbin Syah, bahwa prestasi belajar adalah hasil yang telah dicapai oleh siswa setelah melakukan serangkaian aktivitas belajar yang berupa perubahan tingkah laku baik berupa kognitif, psikomotorik maupun afektif yang bisa dilihat dari prestasi belajar di sekolah. ${ }^{18}$

Menurut Rohmalina Wahab bahwa faktor-faktor yang dapat memengaruhi prestasi belajar dan mengklasifikasikannya menjadi dua bagian, yaitu: a. faktor-faktor intern; dan b. faktor-faktor ekstern.

Faktor-faktor intern, faktor-faktor yang berasal dari dalam diri seseorang yang dapat memengaruhi prestasi belajarnya. Di antara faktor-faktor intern yang dapat memengaruhi

15 Muhibbin Syah, "Psikologi Pendidikan dengan Pendekatan Baru, Edisi Revisi" (Bandung: Remaja Rosdakarya, 2002), 87.

${ }^{16}$ Nana Sudjana, "Cara Belajar Siswa Aktif dalam Proses Belajar Mengajar" (Bandung: Sinar Baru Algensido, 1996), 8.

${ }^{17}$ Slameto, “Belajar\&Faktor-Faktor Yang Memengaruhi” (Jakarta: Rineka Citra, 2010), 2.

${ }^{18}$ Muhibbin Syah, "Psikologi Pendidikan dengan Pendekatan Baru, Edisi Revisi", 43. 
prestasi belajar seseorang adalah antara lain: a. Kecerdasan/Intelegensi, b. Bakat, c. Minat, d. Motivasi.

Adapun faktor-faktor ekstern menurut Rohmalina Wahab, yaitu faktor-faktor yang dapat memengaruhi prestasi belajar seseorang yang sifatnya berasal dari luar diri seseorang tersebut. Yang termasuk faktor-faktor ini adalah antara lain: a. Keadaan lingkungan keluarga, b. Keadaan lingkungan sekolah, c. keadaan lingkungan masyarakat. ${ }^{19}$

Berdasarkan penjelasan diatas penulis dapat menyimpulkan bahwa prestasi belajar meruapakan hasil dati pengukuran terhadap peserta didik yang meliputi berupa kognitif, psikomotorik dan afektif setelah mengikuti proses pembelajaran yang diukur dengan menggunakan intrumen tes yang relavan. Sedangkan dalam dunia pendidikan, bentuk penilaian dari suatu prestasi biasanya dapat dilihat atau dinyatakan dalam bentuk simbol haruf atau angka-angka. Jadi, prestasi belajar adalah hasil yang diraih oleh peserta didik dari aktivitas belajarnya yang ditempuh untuk memperoleh pengetahuan dan keterampilan yang dapat diwujudkan dengan adanya perubahan sikap dan tingkah laku dan pada umumnya dinyatakan dalam bentu simbol atau angka-angka.

Menurut pendapat Wirawan ${ }^{20}$ pekerjaan adalah suatu kelompok posisi yang terdiri atas sejumlah tugas. Sedangkan menurut pendapat Damsar pekerjaan merupakan suatu rangkaian aktivitas untuk memperoleh pendapatan dalam rangka pemenuhan kebutuhan hidup. Oleh karena pekerjaan dipandang sebagai cara pemenuhan kebutuhan hidup, ketika kebutuhan telah dipenuhi, maka pekerjaan tersebut dilakukan seadanya sepanjang apa yang dilakukan tidak memengaruhi perolehan pendapatan yang pada gilirannya memenuhi kebutuhan hidup.

Bekerja adalah melakukan kegiatan dengan maksud memperoleh atau membantu memperoleh penghasilan atau keuangan selama paling sedikit satu jam dalam satu minggu yang lalu. Waktu bekerja tersebut harus berurutan dan tidak terputus. Orang yang bekerja karena sesuatu hal ada yang sementara tidak bekerja, yang didefinisikan sebagai berikut. Mempunyai pekerjaan tetapi sementara tidak bekerja adalah kegiatan dari mereka yang mempunyai pekerjaan tetapi selama seminggu yang tidak bekerja karena suatu sebab

\footnotetext{
${ }^{19}$ Rohmalina Wahab, "Psikologi Belajar", 248.

${ }^{20}$ Wirawan, "Evaluasi Kinerja Sumber Daya Manusia" (Jakarta: Salemba Empat, 2012), 51.
} 
seperti sakit, cuti, menunggu panenan dan mogok. Termasuk mereka yang sudah diterima bekerja, tetapi selama seminggu yang lalu belum bekerja.

Adapun perintah bekerja sudah dijelaskan dalam Al-qur'an, Allah SWT berfirman dalam surat At-Taubah ayat 105:

Artinya: "Dan Katakanlah: "Bekerjalah kamu, Maka Allah dan rasul-Nya serta orang-orang mukmin akan melihat pekerjaanmu itu, dan kamu akan dikembalikan kepada (Allah) yang mengetahui akan yang ghaib dan yang nyata, lalu diberitakanNya kepada kamu apa yang Telah kamu kerjakan. (Kemenag, RI. 2011)

Dari ayat di atas sangatlah jelas bahwa bekerja merupakan kewajiban semua umat muslim. Segala bentuk pekerjaan atau perbuatan bagi seorang muslim dilakukan dengan sadar dan dengan tujuan yang jelas yaitu sebagai bentuk pengabdian kepada Allah SWT.

Jika seseorang hanya mempunyai satu pekerjaan maka pekerjaan tersebut digolongakan sebagai pekerjaan utama. Dalam hal pekerjaan yang dilaksanakan lebih dari satu, maka penentuan pekerjaan utama adalah waktu terbanyak yang digunakan. Sedangkan jika waktu yang digunakan sama maka penghasilan yang terbesar sebagai pekerjaan utama. Jika penghasilan dan waktu yang digunakan sama maka pekerjaan utama tergantung kepada jawaban responden.

Berdasarkan penjelasan di atas penulis dapat menyimpulkan bahwa pekerjaan merupakan suatu kegiatan untuk memperoleh penghasilan atau keuangan selama paling sedikit satu jam dalam satu minggu yang teridiri atas sejumlah tugas. Dengan bekerja bersungguh-sungguh dan senantiasa diiringi doa kepada kepada Allah, kebaikan di dunia berupa kemuliaan, kewibawaan dan kemakmuran akan diperoleh sebagai anugerah kebaikan dariNya.

Jenis pekerjaan adalah macam pekerjaan yang dilakukan oleh seseorang atau ditugaskan kepada seseorang di tempat bekerja. ${ }^{21}$

Begitupun dengan status sosial orang tua mempunyai pengaruh terhadap tingkah laku dan pengalaman anak-anaknya. Yang dimaksud dengan status sosial ialah kedudukan

${ }^{21}$ Basir Barthos, "Manajemen Sumber Daya Manusia: Suatu Pendekatan makro" (Jakarta: PT Bumi Aksara, 2012), 17-18. 
orang dalam kelompokmya. Status disini dapat bersifat statis dapat pula dinamis. Secara sederhana di dalam masyarakat Indonesia terdapat beberapa status sosial ialah : ${ }^{22}$

a. Petani : Mereka yang hidup dari pengusahaan sawah di desa yang suasana kehidupan dalam masyarakat ditandai oleh sifat kekeluargaan

b. Pegawai Negeri : Mereka yang menerima gaji dari pemerintah tiap bulan secara menentu dan kerjanya juga menentu.

c. Angkatan bersenjata : Anggota salah satu 4 angkatan darat, angkatan laut, angkatan udara dan angkatan kepolisian. Mereka menerima gaji dari pemerintah secara menentu.

d. Pedagang : Mereka yang hidup dari keuntungan, yang mereka diperoleh dari pekerjaan jual beli. Hasilnya tidak menentu kerjanyapun juga kurang menentu.

e. Buruh : Buruh diartikan sebagai orang yang bekerja dibawah perintah orang lain, dengan menerima upah karena telah melakukan pekerjaan diperusahaan. Buruh juga adalah mereka yang bekerja dan menggantungkan hidupnya dari gaji dan mendapat upah dari jasa atau tenaga yang dikeluarkannya. ${ }^{23}$

Berdasarkan penjelasan di atas penulis menyimpulkan bahwa setiap keluarga memiliki kebiasaan yang berlainan dengan keluarga lain, sehingga perkembangan anakpun juga berlainan. Di dalam hal ini status orang tua memegang peranan yang penting. Kebiasaan sehari-hari yang terdapat di dalam keluarga banyak dipengaruhi atau terbawa oleh status orang tua. Dan pekerjaan orang tua akan memengaruhi pendidikan anaknya, sehingga menjadikan anak berprestasi.

\section{Data Prestasi Belajar Siswa Keluarga Pegawai Negeri Sipil (PNS) dan Siswa Keluarga Buruh}

Pada penelitian ini penulis dalam mengambil sampel menggunakan teknik Rondom sampling dengan cara purposive sampling, yaitu pengambilan sampel didasarkan atas sifat, pertimbangan-pertimbangan atau ciri-ciri tertentu yang dianggap memiliki hubungan yang erat dengan populasi yang sudah diketahui sebelumnya.

Mengenai pengambilan sampel Suharsimi Arikunto berpendapat sebagai berikut :

${ }^{22}$ Abu Ahmadi, "Psikologi Sosial" (Jakarta: PT Rineka Cipta, 1991), 249.

${ }^{23}$ Halili Toha dan Pramono. 1987."Hubungan Kerja dan Buruh". Jakarta: PT. Rineka Cipta, 1987), 3. 
“Untuk sekedar ancer-ancer, maka apabila subjeknya kurang dari 100, lebih baik diambil semua sehingga penelitiannya merupakan penelitian populasi. Selanjutnya jika subjeknya cukup besar dapat diambil antara $10-15 \%$ atau 20-25\% atau lebih".

Penentuan sample dalam penelitian ini penulis mengambil sample seluruh dari jumlah populasi yaitu 140 siswa Sekolah Menengah Pertama (SMP) Negeri 7 Kota Cirebon siswa 80 siswa buruh dan 60 siswa PNS. Karena sesuai dengan Suharsimi Arikunto apabila subjeknya kurang dari 100 lebih baik diambil semua sehingga penelitiannya merupaka penelitian populasi.

Sebagai sampel penelitian, penulis mengambil sampel kelas VIII A-VIII K yang berjumlah 140 siswa. Siswa yang berkeluarga Pegawai Negeri Sipil (PNS) dengan keseluruhan 60 siswa untuk dijadikan penelitian.

\section{Tabel 1}

\begin{tabular}{|c|c|c|}
\hline No & Nama & Nilai \\
\hline 1 & Responden & \begin{tabular}{|l|}
77 \\
\end{tabular} \\
\hline 2 & Responden & 72 \\
\hline 3 & Responden & 76 \\
\hline 4 & Responden & 70 \\
\hline 5 & Responden & 72 \\
\hline 6 & Responden & 65 \\
\hline 7 & Responden & 73 \\
\hline 8 & Responden & 77 \\
\hline 9 & Responden & 75 \\
\hline 10 & Responden & 65 \\
\hline 11 & Responden & 72 \\
\hline 12 & Responden & 74 \\
\hline 13 & Responden & 68 \\
\hline 14 & Responden & 75 \\
\hline 15 & Responden & 75 \\
\hline 16 & Responden & \begin{tabular}{|l|}
70 \\
\end{tabular} \\
\hline
\end{tabular}




\begin{tabular}{|c|c|c|}
\hline 17 & Responden & 71 \\
\hline 18 & Responden & 68 \\
\hline 19 & Responden & 75 \\
\hline 20 & Responden & 70 \\
\hline 21 & Responden & 72 \\
\hline 22 & Responden & 75 \\
\hline 23 & Responden & 67 \\
\hline 24 & Responden & 74 \\
\hline 25 & Responden & 78 \\
\hline 26 & Responden & 73 \\
\hline 27 & Responden & 65 \\
\hline 28 & Responden & 71 \\
\hline 29 & Responden & 70 \\
\hline 30 & Responden & 72 \\
\hline 31 & Responden & 68 \\
\hline 32 & Responden & 66 \\
\hline 33 & Responden & 78 \\
\hline 34 & Responden & 72 \\
\hline 35 & Responden & 68 \\
\hline 36 & Responden & 75 \\
\hline 37 & Responden & 76 \\
\hline 38 & Responden & 66 \\
\hline 39 & Responden & 75 \\
\hline 40 & Responden & 75 \\
\hline 41 & Responden & 70 \\
\hline 42 & Responden & 72 \\
\hline 43 & Responden & 76 \\
\hline 44 & Responden & 68 \\
\hline 45 & Responden & 74 \\
\hline 46 & Responden & 66 \\
\hline
\end{tabular}




\begin{tabular}{|l|l|l|}
\hline 47 & Responden & 76 \\
\hline 48 & Responden & 68 \\
\hline 49 & Responden & 67 \\
\hline 50 & Responden & 72 \\
\hline 51 & Responden & 68 \\
\hline 52 & Responden & 65 \\
\hline 53 & Responden & 72 \\
\hline 54 & Responden & 66 \\
\hline 55 & Responden & 72 \\
\hline 56 & Responden & 70 \\
\hline 57 & Responden & 70 \\
\hline 58 & Responden & 75 \\
\hline 59 & Responden & 72 \\
\hline 60 & Responden & 70 \\
\hline
\end{tabular}

Sumber Data: Nilai Raport kelas VIII SMP Negeri 7 Kota Ciebon

Siswa yang berkeluarga Buruh sebanyak 80 siswa untuk dijadikan penelitian.

\section{Tabel 2}

\begin{tabular}{|l|l|l|}
\hline No & Nama & Nilai \\
\hline 1 & Responden & 80 \\
\hline 2 & Responden & 82 \\
\hline 3 & Responden & 78 \\
\hline 4 & Responden & 77 \\
\hline 5 & Responden & 78 \\
\hline 6 & Responden & 79 \\
\hline 7 & Responden & 82 \\
\hline 8 & Responden & 80 \\
\hline 9 & Responden & 78 \\
\hline 10 & Responden & 82 \\
\hline 11 & Responden & 79 \\
\hline 12 & Responden & 79 \\
\hline
\end{tabular}




\begin{tabular}{|c|c|c|}
\hline 13 & Responden & 78 \\
\hline 14 & Responden & 80 \\
\hline 15 & Responden & 78 \\
\hline 16 & Responden & 80 \\
\hline 17 & Responden & 78 \\
\hline 18 & Responden & 82 \\
\hline 19 & Responden & 79 \\
\hline 20 & Responden & 78 \\
\hline 21 & Responden & 82 \\
\hline 22 & Responden & 78 \\
\hline 23 & Responden & 79 \\
\hline 24 & Responden & 82 \\
\hline 25 & Responden & 78 \\
\hline 26 & Responden & 84 \\
\hline 27 & Responden & 82 \\
\hline 28 & Responden & 78 \\
\hline 29 & Responden & 85 \\
\hline 30 & Responden & 78 \\
\hline 31 & Responden & 76 \\
\hline 32 & Responden & 85 \\
\hline 33 & Responden & 82 \\
\hline 34 & Responden & 81 \\
\hline 35 & Responden & 83 \\
\hline 36 & Responden & 82 \\
\hline 37 & Responden & 82 \\
\hline 38 & Responden & 83 \\
\hline 39 & Responden & 84 \\
\hline 40 & Responden & 84 \\
\hline 41 & Responden & 78 \\
\hline 42 & Responden & 82 \\
\hline
\end{tabular}




\begin{tabular}{|c|c|c|}
\hline 43 & Responden & 85 \\
\hline 44 & Responden & 76 \\
\hline 45 & Responden & 80 \\
\hline 46 & Responden & 82 \\
\hline 47 & Responden & 85 \\
\hline 48 & Responden & 80 \\
\hline 49 & Responden & 85 \\
\hline 50 & Responden & 78 \\
\hline 51 & Responden & 83 \\
\hline 52 & Responden & 78 \\
\hline 53 & Responden & 82 \\
\hline 54 & Responden & 80 \\
\hline 55 & Responden & 80 \\
\hline 56 & Responden & 82 \\
\hline 57 & Responden & 87 \\
\hline 58 & Responden & 80 \\
\hline 59 & Responden & 81 \\
\hline 60 & Responden & 81 \\
\hline 61 & Responden & 82 \\
\hline 62 & Responden & 78 \\
\hline 63 & Responden & 85 \\
\hline 64 & Responden & 81 \\
\hline 65 & Responden & 80 \\
\hline 66 & Responden & 81 \\
\hline 67 & Responden & 86 \\
\hline 68 & Responden & 80 \\
\hline 69 & Responden & 78 \\
\hline 70 & Responden & 85 \\
\hline 71 & Responden & 75 \\
\hline 72 & Responden & 85 \\
\hline
\end{tabular}




\begin{tabular}{|l|l|l|}
\hline 73 & Responden & 83 \\
\hline 74 & Responden & 75 \\
\hline 75 & Responden & 82 \\
\hline 76 & Responden & 80 \\
\hline 77 & Responden & 78 \\
\hline 78 & Responden & 78 \\
\hline 79 & Responden & 77 \\
\hline 80 & Responden & 82 \\
\hline
\end{tabular}

Sumber Data: Nilai Raport kelas VIII SMP Negeri 7 Kota Ciebon

\section{Analisis Data Prestasi Belajar Siswa Keluarga Pegawai Negeri Sipil (PNS) dan Siswa Keluarga Buruh}

Hasil analis data penulis dapatkan dari raport semester ganjil kelas VIII yang penulis lakukan terhadap 140 siswa, 60 siswa keluarga PNS dan siswa keluarga Buruh. Adapun untuk mengetahui prestasi belajar antara siswa keluarga PNS dengan siswa keluarga Buruh dapat dilihat dari hasil perhitungan yang penulis lakukan di bawah ini:

\section{a. Deskripsi Data}

1) Prestasi siswa keluarga Pegawai Negeri Sipil (PNS) pada mata pelajaran PAI berdasarkan hasil perhitungan dari output hitungan manual nilai rata-rata prestasi belajar, diketahui nilai rata-rata (mean) siswa keluarga PNS yaitu dengan nilai 71, 42. Untuk nilai pretasi belajar siswa keluarga PNS berada pada kreteria 56-71 dimana berada pada katagori Cukup. Untuk mengetahui hasil sebelum dan sesudah prestasi belajar adalah dengan mencari rata-rata (Mean) data dari nilai raport berikut:

Untuk mencari mean digunakan rumus sebagai berikut :

Keterangan :

$\mathrm{M}=$ Mean

$\sum=$ jumlah

$\mathrm{N}=$ banyaknya siswa

$\mathrm{X}=$ Skor

$\mathrm{Mx}=\frac{\sum \mathrm{x}}{\mathrm{N}}$ 
$=\frac{4285}{60}$

$=71,42$

Berdasarkan data diatas maka dapat digambarkan bahwa ditemukan ratarata (mean) siswa keluarga Pegawai Negeri Sipil senilai 71,42.

2) Prestasi siswa keluarga Buruh pada mata pelajaran PAI berdasarkan hasil perhitungan dari output hitungan manual nilai rata-rata prestasi belajar, diketahui nilai rata-rata (mean) siswa keluarga PNS yaitu dengan nilai 80,64. Untuk nilai pretasi belajar siswa keluarga PNS berada pada kreteria 72-85 dimana berada pada katagori Baik. Untuk mengetahui hasil sebelum dan sesudah prestasi belajar adalah dengan mencari rata-rata (Mean) data dari nilai raport berikut:

Untuk mencari mean digunakan rumus sebagai berikut :

Keterangan :

$\mathrm{M}=$ Mean

$\sum=$ jumlah

$\mathrm{N}=$ banyaknya siswa

$\mathrm{X}=$ Skor

$M x=\frac{\sum x}{N}$

$=\frac{6451}{80}$

$=80,64$

Berdasarkan perhitungan diatas ditemukan rata-rata (mean) siswa keluarga Buruh senilai 80,64

\section{b. Analisis Data}

Tabel 3

\section{Group Statistics}




\begin{tabular}{|ll|l|l|l|l|}
\hline & & & & & Std. \\
& group & $\mathrm{N}$ & Mean & Deviation & $\begin{array}{l}\text { Error } \\
\text { Mean }\end{array}$ \\
\hline PN & 1 & 60 & 71,42 & 3,674 &, 474 \\
S & 2 & 80 & 80,64 & 2,725 &, 305 \\
\hline
\end{tabular}

Berdasarkan nilai ooput SPSS di atas rata-rata prestasi belajar, diketahui nilai rata-rata siswa keluarga PNS 71, 42 lebih rendah dari nilai rata-rata siswa keluarga Buruh sebesar 80,64. Jadi, terdapat perbedaan prestasi belajar antara keluarga PNS dengan siswa keluarga Buruh.

Untuk mengetahui ada tidaknya perbedaan yang signifikan pada perilaku social siswa keluarga PNS dan siswa keluarga Buruh, maka dalam pengujian hipotesis ini dilakukan dengan menggunkan Uji- T. Adapun hasilnya dapat dilihat pada table berikut:

\section{Tabel 4}

\section{Uji Hipotesis}

\begin{tabular}{|c|c|c|c|c|c|c|c|c|c|c|}
\hline \multicolumn{2}{|c|}{\begin{tabular}{|l}
\multicolumn{2}{l}{ Levene's } \\
Test for \\
Equality of \\
Variances
\end{tabular}} & \multicolumn{9}{|c|}{ t-test for Equality of Means } \\
\hline $\mathrm{F}$ & Sig. & $\mathrm{T}$ & Df & $\begin{array}{l}\text { Sig. } \\
(2- \\
\text { tailed) }\end{array}$ & $\begin{array}{l}\mathrm{Me} \\
\mathrm{Dif} \\
\text { ren }\end{array}$ & \begin{tabular}{l|l} 
In & 1 \\
$\mathrm{e}$ & 1 \\
$\mathrm{e}$ & 1
\end{tabular} & $\begin{array}{l}\text { Std. } \\
\text { Erro } \\
\text { Diff } \\
\text { renc }\end{array}$ & e & $\begin{array}{l}95 \% \\
\text { Con } \\
\text { Inte } \\
\text { the } \\
\text { Diff }\end{array}$ & $\begin{array}{l}\text { o } \\
\text { ffidence } \\
\text { rval of } \\
\text { ference }\end{array}$ \\
\hline $\begin{array}{l}\text { Low } \\
\text { er }\end{array}$ & $\begin{array}{l}\text { Upp } \\
\text { er }\end{array}$ & $\begin{array}{l}\text { Low } \\
\text { er }\end{array}$ & $\begin{array}{l}\text { Upp } \\
\text { er }\end{array}$ & $\begin{array}{l}\text { Low } \\
\text { er }\end{array}$ & $\begin{array}{l}\text { Upp } \\
\text { er }\end{array}$ & $\begin{array}{l}\text { Lo } \\
\text { er }\end{array}$ & & $\begin{array}{l}\text { Up } \\
\text { er }\end{array}$ & & Lower \\
\hline
\end{tabular}




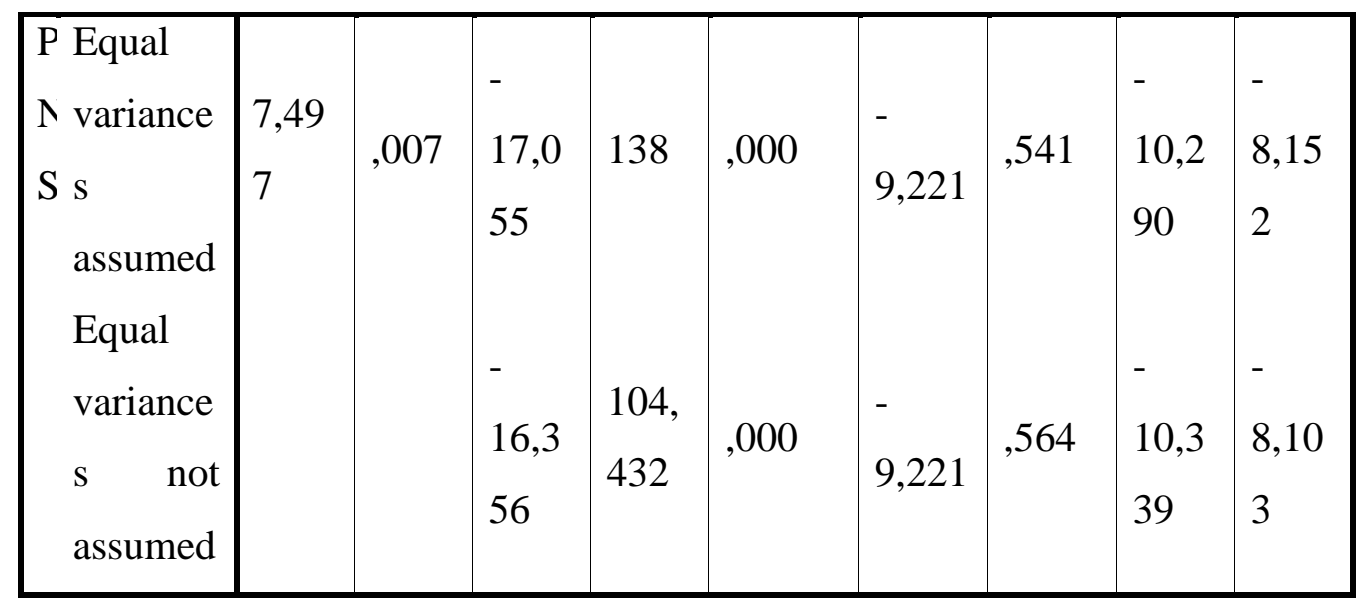

Berdasarkan table diatas, hasil Uji- $\mathrm{T}$ menunjukan Sig. (2- tailed) $0,000<\alpha(0,05)$ sehingga $\mathrm{H}_{0}$ ditolak dan $\mathrm{H}_{\mathrm{a}}$ diterima yang berarti terdapat perbedaan yang signifikan antara prestasi belajar keluarga PNS dengan siswa keluarga buruh.

Dengan selesainya pengujian hipotesis, maka dapat diketahui bahwa rata-rata prsetasi belajar siswa keluarga PNS sebesar 71, 42 lebih rendah dari pada rata-rata prestasi belajar keluarga buruh sebesar 80,64.

Dalam Uji- T (independent Sample T-Test) dapat disimpulkan hasil Uji$\mathrm{T}$ menunjukan Sig. (2- tailed) $0,000<\alpha(0,05)$ sehingga $\mathrm{H}_{0}$ ditolak dan $\mathrm{H}_{\mathrm{a}}$ diterima yang berarti terdapat perbedaan yang siginfikan antara prestasi belajar siswa keluarga PNS dengan siswa keluarga buruh di SMP Negeri 7 kota Cirebon. Karena dilihat dari nilai rata-rata (mean) prestasi belajar keluarga PNS lebih rendah dibanding rata-rata (mean) prestasi belajar siswa keluarga Buruh. Hal ini berarti bahwa prestasi belajar pada mata pelajaran Pendidikan Agama Islam (PAI) siswa keluarga Buruh lebih baik dari pada prestasi belajar siswa keluarga PNS.

\section{KESIMPULAN}

Berdasarkan analisis hasil penelitian yang dilakukan Sekolah Menengah Pertama (SMP) Negeri 7 Kota Cirebon mengenai Prestasi Belajar antara siswa keluarga PNS 
dengan prestasi belajar siswa keluarga Buruh pada mata pelajaran Pendidikan Agama Islam (PAI) dapat disimpulkan sebagai berikut:

1. Prestasi belajar pada mata pelajaran Pendidikan Agama Islam (PAI) siswa kelurga PNS SMP Negeri 7 kota Cirebon diketahui bahwa siswa keluarga PNS prestasinya Cukup. Dilihat dari nilai menunjukan perolehan perhitungan rata-rata (Mean) 71,42. Nilai yang digunakan dan dilihat pada nilai rapot siswa semester ganjil.

2. Prestasi belajar pada mata pelajaran Pendidikan Agama Islam (PAI) siswa kelurga PNS SMP Negeri 7 kota Cirebon diketahui bahwa siswa keluarga Buruh prestasinya Baik. Dilihat dari nilai menunjukan perolehan perhitungan rata-rata (Mean) 80,64. Nilai yang digunakan dan dilihat pada nilai rapot siswa semester ganjil.

3. Hasil Uji- T menunjukan Sig. (2-tailed) $0,000<\alpha(0,05)$ sehingga $\mathrm{H}_{0}$ ditolak dan $\mathrm{H}_{\mathrm{a}}$ diterima yang berarti terdapat perbedaan yang signifikan antara prestasi belajar keluarga PNS dengan siswa keluarga buruh. Jadi, terdapat perbedaan yang siginfikan antara prestasi belajar siswa keluarga PNS dengan siswa keluarga buruh di SMP Negeri 7 kota Cirebon. Karena dilihat dari nilai rata-rata (mean) prestasi belajar keluarga PNS lebih rendah dibanding rata-rata (mean) prestasi belajar siswa keluarga Buruh. Hal ini berarti bahwa prestasi belajar pada mata pelajaran Pendidikan Agama Islam (PAI) siswa keluarga Buruh lebih baik dari pada prestasi belajar siswa keluarga PNS. 


\section{DAFTAR PUSTAKA}

Ahmadi, Abu. 1991."Psikologi Sosial”. Jakarta: PT Rineka Cipta.

Amirah. 2010."Mendidikan Anak di Era Digital". Surabaya: LaksBang Pressindo.

Barthos, Basir. 2012."Manajemen Sumber Daya Manusia: Suatu Pendekatan makro". Jakarta: PT Bumi Aksara.

Ellis Ormroad, Jeanne. 2008."Psikologi Pendidikan". Jakarta: Penerbit Erlangga.

Gerungan,WA. 1988.”Psikologi Sosial”. Jakarta: PT Rineka Cipta.

Mulyono. 2009.”Buku Ajar Pendidikan Islam”. Jakarta: Rineka Cipta.

Purwanto, M. Ngalim. 2013. Psikologi Pendidikan. Bandung: PT.. Remaja Rosdakarya

Sudjana, Nana. 1996."Cara Belajar Siswa Aktif dalam Proses Belajar Mengajar". Bandung: Sinar Baru Algensido.

Slameto, 2010. “Belajar\&Faktor-Faktor Yang Memengaruhi”. Jakarta: Rineka Citra.

Syah, Muhibbin. 2002."Psikologi Pendidikan dengan Pendekatan Baru, Edisi Revisi". Bandung: Remaja Rosdakarya.

Tafsir, Ahmad., dkk. 2004."Cakrawala Pemikiran Pendidikan Islam”. Bandung: Mimbar Pustaka.

Toha, Halili dan Pramono. 1987."Hubungan Kerja dan Buruh". Jakarta: PT. Rineka Cipta. UU RI No. 20. 2003."Sistem Pendidikan Nasional".Jakarta.Sinar Grafika.

Wahab, Rohmalina. 2016."Psikologi Belajar". Depok: PT. Rajagrafindo Persada.

Wirawan. 2012.”Evaluasi Kinerja Sumber Daya Manusia”. Jakarta: Salemba Empat. 